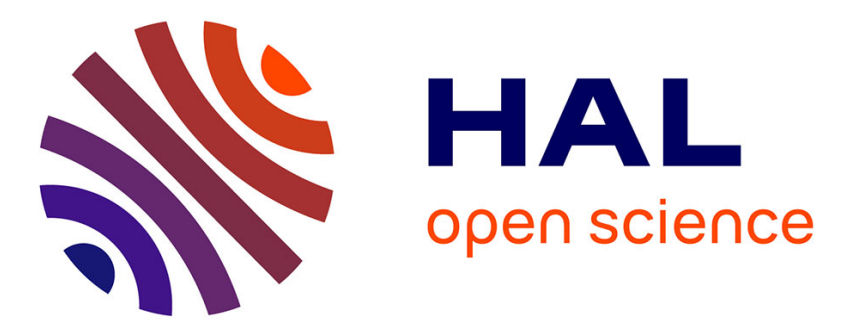

\title{
Paradoxical anti-epileptic effects of a GluR5 agonist of kainate receptors.
}

Ilgam Khalilov, June C. Hirsch, Rosa Cossart, Yehezkel Ben-Ari

\section{To cite this version:}

Ilgam Khalilov, June C. Hirsch, Rosa Cossart, Yehezkel Ben-Ari. Paradoxical anti-epileptic effects of a GluR5 agonist of kainate receptors.. Journal of Neurophysiology, 2002, 88 (1), pp.523-7. inserm00484867

\section{HAL Id: inserm-00484867 https://www.hal.inserm.fr/inserm-00484867}

Submitted on 19 May 2010

HAL is a multi-disciplinary open access archive for the deposit and dissemination of scientific research documents, whether they are published or not. The documents may come from teaching and research institutions in France or abroad, or from public or private research centers.
L'archive ouverte pluridisciplinaire HAL, est destinée au dépôt et à la diffusion de documents scientifiques de niveau recherche, publiés ou non, émanant des établissements d'enseignement et de recherche français ou étrangers, des laboratoires publics ou privés. 
You might find this additional information useful...

This article cites 29 articles, 11 of which you can access free at:

http://jn.physiology.org/cgi/content/full/88/1/523\#BIBL

This article has been cited by 7 other HighWire hosted articles, the first 5 are:

Subunit-Dependent Postsynaptic Expression of Kainate Receptors on Hippocampal Interneurons in Area CA1

J. Wondolowski and M. Frerking

J. Neurosci., January 14, 2009; 29 (2): 563-574.

[Abstract] [Full Text] [PDF]

Neuroprotection of GluR5-containing Kainate Receptor Activation against Ischemic Brain Injury through Decreasing Tyrosine Phosphorylation of N-Methyl-D-aspartate Receptors Mediated by Src Kinase

J. Xu, Y. Liu and G.-Y. Zhang

J. Biol. Chem., October 24, 2008; 283 (43): 29355-29366.

[Abstract] [Full Text] [PDF]

Endogenous Activation of Kainate Receptors Regulates Glutamate Release and Network Activity in the Developing Hippocampus

S. E. Lauri, M. Segerstrale, A. Vesikansa, F. Maingret, C. Mulle, G. L. Collingridge, J. T. R. Isaac and $\mathrm{T}$. Taira

J. Neurosci., May 4, 2005; 25 (18): 4473-4484.

[Abstract] [Full Text] [PDF]

Kainate receptors and rhythmic activity in neuronal networks: hippocampal gamma oscillations as a tool

A. Fisahn

J. Physiol., January 1, 2005; 562 (1): 65-72.

[Abstract] [Full Text] [PDF]

Distinct Roles for the Kainate Receptor Subunits GluR5 and GluR6 in Kainate-Induced Hippocampal Gamma Oscillations

A. Fisahn, A. Contractor, R. D. Traub, E. H. Buhl, S. F. Heinemann and C. J. McBain

J. Neurosci., October 27, 2004; 24 (43): 9658-9668.

[Abstract] [Full Text] [PDF]

Medline items on this article's topics can be found at http://highwire.stanford.edu/lists/artbytopic.dtl

on the following topics:

Biochemistry .. Propionic Acid

Physiology .. Hippocampal Neurons

Veterinary Science .. Hippocampus

Medicine .. Pediatric Seizures

Medicine .. Epilepsy

Neuroscience .. Seizures

Updated information and services including high-resolution figures, can be found at: http://jn.physiology.org/cgi/content/full//88/1/523

Additional material and information about Journal of Neurophysiology can be found at: http://www.the-aps.org/publications/jn

This information is current as of May 19, 2010 . 


\title{
Paradoxical Anti-Epileptic Effects of a GluR5 Agonist of Kainate Receptors
}

\author{
ILGAM KHALILOV, JUNE HIRSCH, ROSA COSSART, AND YEHEZKEL BEN-ARI \\ Institut de Neurobiologie de la Méditerranée, Institut National de la Santé et de la Recherche \\ Médicale, U29, Marseille, France
}

Received 15 October 2001; accepted in final form 24 January 2002

\begin{abstract}
Khalilov, Ilgam, June Hirsch, Rosa Cossart, and Yehezkel Ben-Ari. Paradoxical anti-epileptic effects of a GluR5 agonist of kainate receptors. J Neurophysiol 88: 523-527, 2002; 10.1152/jn.00838.2001. Kainate generates in adult hippocampal neurons a seizure but also a massive excitation of interneurons and a dramatic increase of the inhibitory drive that impinges on principal cells. This "overinhibition" is largely mediated by GluR5-containing kainate receptors that are enriched on interneurons. Here, using the neonatal intact hippocampus in vitro and the triple chamber, we first show that this mechanism is fully operative in neonatal neurons. We then report that application to one hippocampus of ( $R S)$-2-amino-3(5-tert-butyl-3-hydroxy-4-isoxazolyl)propionic acid-a relatively selective agonist of GluR5 containing kainate receptors-depresses the propagation of seizure generated in the opposite hippocampus by a convulsive agent. We conclude that the selective excitation of interneurons by GluR5-containing kainate receptor agonists opens a new therapeutic approach for the epilepsies.
\end{abstract}

\section{N T R O D U C T I O N}

Systemic or intracerebral administration of kainate - an excitatory amino acid extracted from sea weeds-generates a seizure and brain-damage syndrome that mimics several central properties of human temporal lobe epilepsy (Ben-Ari 1985; Nadler 1981). Studies using kainate and kainate analogues in vivo and in slice preparations have shown that kainate generates seizures in the CA3 region-by far the most susceptible brain region to the adverse effect of kainate (Ben-Ari and Gho 1988; Robinson and Deadwyler 1981). These events then propagate to the CA1 region and from there to other limbic structures leading to the occurrence of recurrent limbic seizures and a status epilepticus that will propagate to the rest of the cortical mantle (Ben-Ari and Cossart 2000; Ben-Ari and Gho 1988; Robinson and Deadwyler 1981). The mechanisms underlying these effects have been in part elucidated. Kainate activates high-affinity kainate receptors that are highly expressed on CA3 pyramidal neurons and their mossy fiber synapses (Gaiarsa et al. 1994; Monaghan and Cotman 1982; Tremblay et al. 1985), leading to the generation of synchronized bursts via the recurrent collateral excitatory synapses that interconnect CA3 pyramidal neurons (Miles and Wong 1986; Smith et al. 1995).

Kainate receptors are, however, also enriched on interneurons (Bahn et al. 1994; Bureau et al. 1999; Mulle et al. 1998,

\footnotetext{
Address for reprint requests: Y. Ben-Ari, Inmed U29 INSERM, 163, route de Luminy, 13273 Marseille Cédex 09, France (E-mail:ben-ari@inmed. univ-mrs.fr).
}

2000; Petralia et al. 1994) and the activation of these receptors (Cossart et al. 1998; Frerking et al. 1998) produces a massive excitation of interneurons and a dramatic increase of the tonic inhibitory drive that impinges on the principal cells. Because of the important role of GABAergic inhibition in preventing the generation of seizures, this action is somewhat paradoxical as it may exert an anti epileptic effect. The aim of the present study was therefore to examine the functional consequences of a selective activation of kainate receptors located on interneurons. We relied on the observation that GluR5-containing kainate receptors are enriched in interneurons (Bahn et al. 1994; Bureau et al. 1999; Mulle et al. 1998, 2000; Petralia et al. 1994) and that their activation by the relatively selective agonist $(R S)$-2-amino-3-(5-tert-butyl-3-hydroxy-4-isoxazolyl)propionic acid (ATPA) (Clarke et al. 1997) excites interneurons and augments the tonic GABAergic inhibition that impinges on pyramidal neurons (Cossart et al. 1998). We have used the in vitro intact neonatal hippocampus (Khalilov et al. 1997b) and a triple chamber that enables the two hippocampi and their connecting commissures to be in three independent chambers (Khalilov et al. 1999a). In this chamber, it is possible to apply a convulsive agent to one hippocampus and test whether a putative anti-epileptic agent prevents the propagation of the seizure to the other hippocampus. This enables to avoid possible interferences between convulsive and anti-epileptic agents.

\section{METHODS}

The intact preparation that we used as well as the triple chamber have been described elsewhere (Khalilov et al. 1997, 1999). We used the intact hippocampal formations (IIHFs) of neonatal (P6-P7) Wistar rats that were placed into a conventional fully submerged chamber and perfused with $\mathrm{ACSF}$ at $30-32^{\circ} \mathrm{C}$ at a rate of $8-10 \mathrm{ml} / \mathrm{min}$. Whole cell recordings were performed with patch electrodes with a resistance of 5-8 $\mathrm{M} \Omega$ when filled with solutions containing (in $\mathrm{mM}$ ): 135 K-gluconate, $0.1 \mathrm{CaCl}_{2}, 2 \mathrm{MgCl}_{2}, 2 \mathrm{Na} 2 \mathrm{ATP}, 1 \mathrm{EGTA}$, and 10 HEPES, pH 7.25, ([ $\left.\mathrm{Cl}^{-}\right]$in $\left.=4.2 \mathrm{mM}\right), \mathrm{pH} 7.25$, osmolarity, 280 mosm. Tungsten bipolar electrodes disposed in the stratum radiatum of CA3 area were used to evoke synaptic responses. All neurons were filled with dyes and reconstructed post hoc for identification.

Group measures are expressed as means \pm SE, error bars also indicate SE. Statistical significance of differences was assessed with the Students $t$-test, the level of significance was set at $P<0.05$. Drugs

The costs of publication of this article were defrayed in part by the payment of page charges. The article must therefore be hereby marked "advertisement" in accordance with 18 U.S.C. Section 1734 solely to indicate this fact. 
used were purchased from Cookson-Tocris [6-cyano-7-nitroquinoxalene-2,3-dione (CNQX) and 2-amino-5-phosphonovaleric acid (DAPV)], Sigma (bicuculline, kainate, biocytin), and Alamone (TTX). ATPA was kindly provided by Lilly (Lilly Research Center).

\section{R E S UL T S}

ATPA excites interneurons and inhibits pyramidal neurons in the neonatal hippocampus

In an earlier study, we had demonstrated that the activation of GluR5-containing kainate receptors increased GABAergic inhibition in adult hippocampal slices (Cossart et al. 1998). We thus first tested whether this effect is also valid in neonatal neurons. We used P6-P7 intact preparations as the activation of GABAergic synapses generates at this age primarily a hyperpolarization (Ben-Ari et al, 1989). Bath application of ATPA $(1 \mu \mathrm{M})$ produced opposite effects on cell excitability in simultaneously recorded CA1 interneurons and pyramidal neurons. In cell-attached recordings (Fig. 1, A and B), ATOA (1 $\mu \mathrm{M})$ increased the action potential discharges of interneurons and reduced that of pyramidal neurons. In whole cell record- ings at resting membrane potential, ATPA produced a hyperpolarization of pyramidal neurons $(x=7.1 \pm 1.1 \mathrm{mV}, n=10)$ in current-clamp conditions (Fig. 1C) and a dramatic increase of the frequency of spontaneous inhibitory postsynaptic currents (sIPSCs; $x=1,250.4 \pm 201.2 \%, n=5$ ). Therefore in neonatal neurons, the activation of GluR5 agonists induces an increase of the inhibitory drive via a depolarization of interneurons.

\section{ATPA prevents the propagation of seizures from one hemisphere to the other}

To determine the effects of ATPA on the propagation of epileptiform activities from one hemisphere to the other, field and patch-clamp recordings were made from both hemispheres. Bath application of high $\left[\mathrm{K}^{+}\right]_{\mathrm{o}}(7 \mathrm{mM})$, bicuculline $(3$ $\mu \mathrm{M})$, or 4 -AP $(50 \mu \mathrm{M})$ to one hippocampus generated recurrent spontaneous and evoked inter-ictal episodes (Fig. 2). These are mediated by glutamatergic excitatory postsynaptic currents and are inward at $V_{\mathrm{m}}-45 \mathrm{mV}$ (Fig. $2 C$ ). These events rapidly propagated to the contralateral hippocampus, (Fig. 2D,

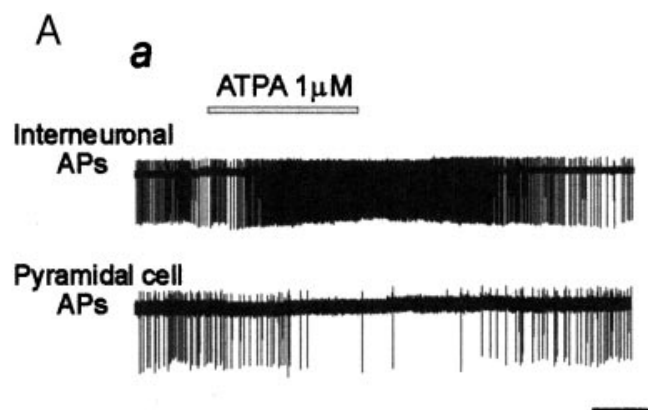

$\overline{2 \mathrm{~min}}$

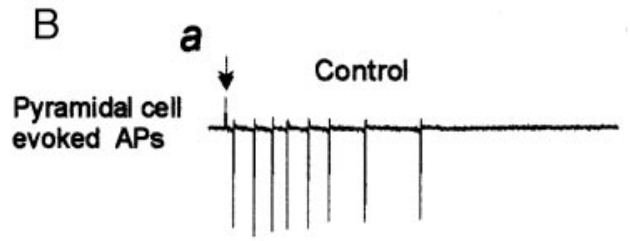

C

a

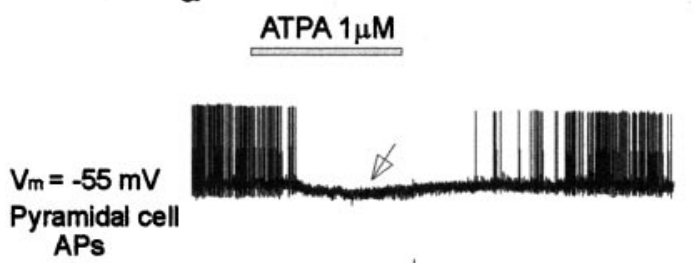

b

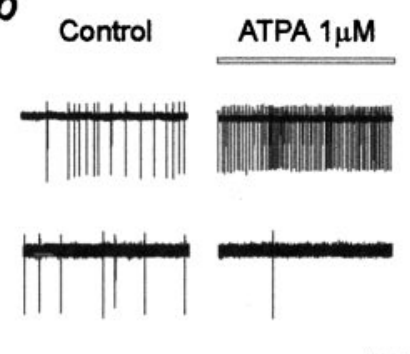

C

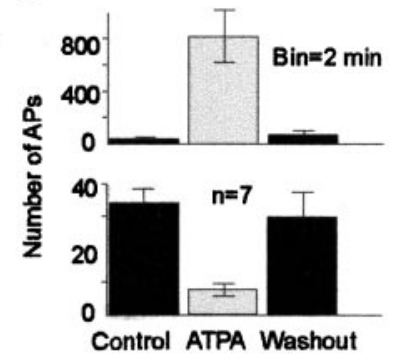

C

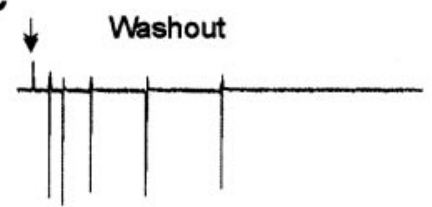

C b

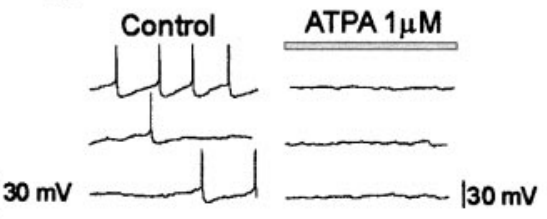

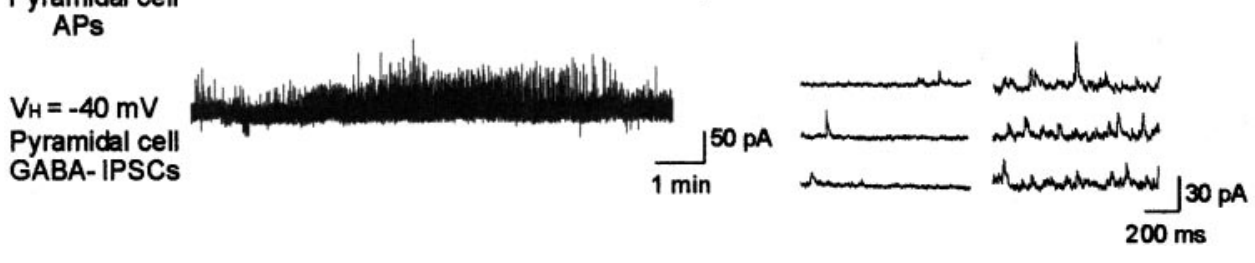

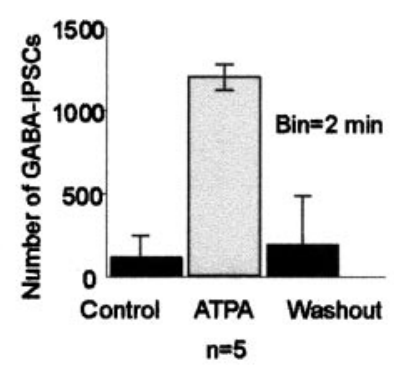

FIG. 1. (RS)-2-amino-3-(5-tert-butyl-3-hydroxy-4-isoxazolyl)propionic acid (ATPA) excites interneurones and inhibits pyramidal cells. A: paired recordings in the cell attached configuration from a P6 intact hippocampus in vitro. Note that ATPA produced a more than 40-fold increase of the frequency of action potentials in the interneuron and an almost full blockade of the discharge of the pyramidal neuron. $B$ : electrical stimulation generated a barrage of action potentials in a pyramidal neuron. This was fully blocked by ATPA. $C$ : paired recordings from 2 pyramidal neurons in whole cell configuration current clamp (top) and voltage clamp (bottom). Note that ATPA produced a hyperpolarization (top) and a massive increase of the frequency of the ongoing spontaneous inhibitory postsynaptic currents (sIPSCs; bottom). Quantitative data are presented in the right side of the figure. 


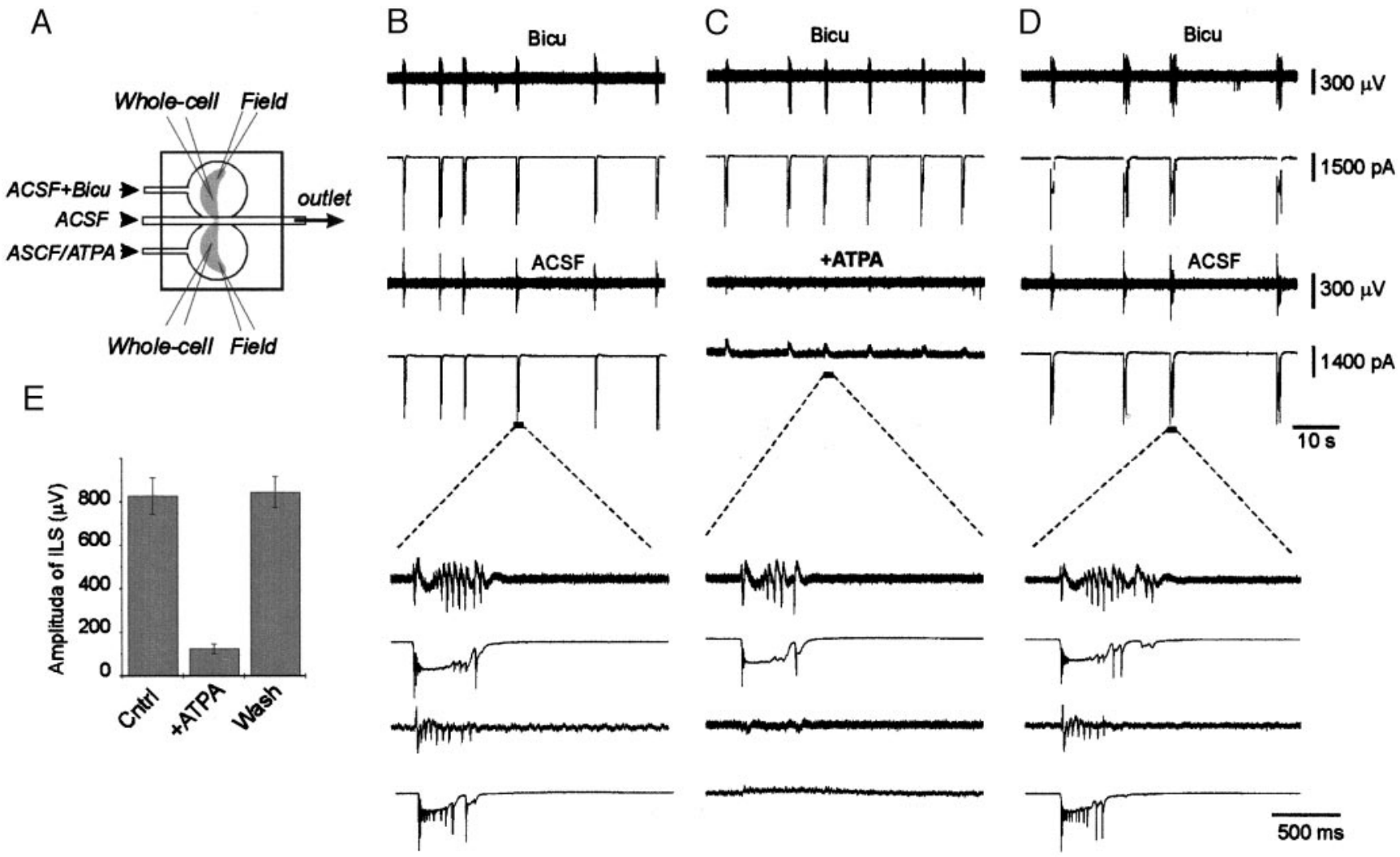

FIG. 2. ATPA prevents the propagation of seizures from 1 hemisphere to the other. $A$ : triple chamber preparation, recordings include both field and whole cell recordings from both hippocampi. $B$ : application of bicuculline $(2 \mu \mathrm{M})$ to 1 hippocampus generated inter-ictal-like seizures (ILS) that propagated to the contralateral side. $C$ : bicuculline-induced seizures failed to propagate to the contralateral hemisphere when ATPA $(1 \mu \mathrm{M})$ was present. $D$ : washing out of ATPA enabled the propagation of seizures to the contralateral hippocampus. Bottom: the same data at a faster display. Quantification of the effects of ATPA is shown in $E$.

mean latency of $25.3 \pm 0.8 \mathrm{~ms}, n=24)$. Applications of ATPA $(1 \mu \mathrm{M})$ to the contralateral naïve hippocampus that did not receive the convulsive agent considerably reduced the propagation of seizures (Fig. $2 \mathrm{C}$ ). Thus in most experiments (65\% of the experiments, $n=17$ ), it produced a complete blockade of epileptiform events in the remaining experiments it reversibly decreased both the amplitude and duration of inter-ictal events $(66.4 \pm 1.2$ and $75 \pm 5.0 \%$ of the control value, respectively, $n=6$ ). During the application of ATPA, GABAergic currents were recorded in the contralateral hippocampus and glutamatergic ones in the treated hippocampus (Fig. 2C). On wash-out of ATPA, the seizures rapidly propagated to the opposite hippocampus (Fig. 2D). Bath applications of ATPA after the seizures had been generated in the contralateral hippocampus, similarly blocked the propagated seizures (not shown).

\section{I S C U S S I O N}

We show that the activation of GluR5-containing kainate receptors by ATPA prevents the propagation of epileptiform events from one hemisphere to the other. Although the exact mechanisms underlying these effects have not been determined, the powerful excitation of interneurons and the dramatic increase of the tonic inhibition that it generates most likely play an important role. However, ATPA is not entirely specific for GluR5-containing receptors (Paternain et al. 2000), and the present results are in disagreement with studies by
Lerma and co-workers that suggest that kainate reduces inhibition in adult neurons (Ben-Ari and Cossart, 2000, 2001; Lerma 2001; Lerma et al. 2001). Also, the effects of ATPA on interneurons are reduced but not fully blocked by a selective KO of GluR5-containing receptors; a double KO of GluR5 and -6 is required to produce a full blockade of the actions of ATPA (Mulle et al. 2000). Finally, several interneurons-in particular in stratum radiatum - are not excited by ATPA (Cossart et al.) suggesting that other mechanisms may be involved in the actions of kainate. In spite of this, our data are best explained by a direct excitation of interneurons and a reduction of the excitability in principal cells. Our observations should provide a novel approach to reduce the excitability of principal cells in a cortical network and possibly prevent seizure generation. The use of the triple chamber provides a unique opportunity to test these actions without the possible interferences between the convulsive and anti-epileptic actions of an agent.

Several features of the actions of ATPA, kainate- or other activators of kainate receptors located on interneurons-are particularly useful to consider in relation to its suggested anti-epileptic properties. First, the excitation of CA1 interneurons by these agents is specific because similar applications of kainate or ATPA do not excite CA1 pyramidal neurons (Cossart et al. 1998). Second, this effect is dramatic and persistent, it is associated with an 8- to 10-fold increase of the frequency of GABAergic IPSCs in pyramidal neurons that can persist for long durations (Cossart et al. 1998; present study). Third, the 
synaptic input activated by kainate receptors in interneurons is quite powerful as it readily generates action potentials and produces an important increase in the excitability of interneurons (Cossart et al. 1998; present study). Nevertheless, it is important to stress that other actions of ATPA could contribute to the observed effects. Recent studies suggest that kainate receptor activation could also reduce glutamate release by a presynaptic mechanism (Contractor et al. 2000; Frerking et al. 2001). Further studies are required to determine the contributions of these actions to the anti-epileptic actions of GluR5 agonists.

Our suggestion of paradoxical anti epileptic effects of a kainate receptor agonist is not incompatible with the epileptogenic effects of kainate. Kainate exerts a multitude of actions on different types of neurons and different channels. The result - the seizure-is the consequence of these diverse actions. Thus seizures are generated in the adult hippocampus primarily because of the activation of the mossy fiber synapses that are enriched with the GluR6-containing kainate receptors. Both the knock-out of the GluR6 genes (Mulle et al. 1998) and the selective lesion of the mossy fibers by neonatal irradiation prevent the effects of kainate. Also, GABAergic inhibition is not abolished in epileptic animals; there is rather a reduction of tonic inhibition restricted to the dendrites of pyramidal neurons - as a result of the degeneration of a subpopulation of interneurons during the initial status epilepticus. In contrast, tonic inhibition is increased in the somata of the principal cells raising the possibility of a paradoxical increase of inhibition in the epileptic circuit (Cossart et al. 1998, 2001). As interneurons are capable of high-frequency discharge, we suggest that the activation by GluR5 agonists of surviving interneurons may in part replace the missing inhibitory drive. Preliminary experiments suggest that the actions of ATPA are preserved in neurons recorded in slices obtained from epileptic rats (Hirsch, unpublished observations).

Further studies are also required to determine the maturation of the actions of ATPA. Indeed early during development, GABA provides most of the excitatory drive because of a different chloride gradient (Ben-Ari 2000; Ben-Ari et al. 1989). In our studies, ATPA prevented the propagation of seizures even when GABA generated a depolarization in the recorded neuron (not shown). This is best explained by the dual excitatory and shunting actions of GABA shown in neonatal hippocampal neurons (Khalilov et al. 1999a). Future studies will also have to compare the maturation of the epileptogenic actions of kainate (see Khalilov et al. 1999b) to the development of the effects of ATPA. Immuno-cytochemical data suggest that interneurons possess GluR5 mRNA already at birth (Bahn et al. 1994).

In conclusion, our results suggest that the activation of GluR5-containing kainate receptors can prevent the propagation of seizure from one hemisphere to the other. Kainate will generate seizure but at the same time augment the excitatory input to interneurons and thus lead to an increased inhibition. The observation that these actions may be mediated by different subunits will enable to develop selective drugs that predominantly act to reduce seizures. The use of the newly developed triple chamber provides a unique possibility to record from both hemispheres and determine the effects of various procedures and agents on the generation and propagation of activities from one hemisphere to the other.
This work was supported by Institut National de la Santé et de la Recherche Médicale, the French League against Epilepsy (LFCE), and a grant from the Foundation Electricity of France to I. Khalilov.

Present address of I. Khalilov: Kazan Institute of Biochemistry and Biophysics, Kazan, Russia.

\section{REFERENCES}

Bahn S, VolK B, AND Wisden W. Kainate receptor gene expression in the developing rat brain. J Neurosci 14: 5525-5547, 1994.

BEN-ARI Y. Limbic seizure and brain damage produced by kainic acid: mechanisms and relevance to human temporal lobe epilepsy. Neuroscience 14: 375-403, 1985.

BEN-ARI Y. Developing networks play a similar melody [review]. Trends Neurosci 24: 6:353-360, 2001.

Ben-Ari Y, Cherubini E, Coradetti R, and Gaiarsa JL. Giant synaptic potentials in immature rat CA3 hippocampal neurones. $J$ Physiol (Lond) 416: 303-325, 1989

BEN-ARI Y AND COSSART R. Kainate, a double agent that generates seizures: two decades of progress. Trends Neurosci 23: 580-587, 2000.

BEN-ARI Y AND COSSART R. Kainate receptors keep the excitement high: reply. Trends Neurosci 24: 141-143, 2001.

BEN-ARI Y AND GHO M. Long-lasting modification of the synaptic properties of rat CA3 hippocampal neurones induced by kainic acid. $J$ Physiol (Lond) 404: 365-384, 1988.

Bureau I, Bischoff S, Heinemann SF, and Mulle C. Kainate receptormediated responses in the CA1 field of wild-type and GluR6-deficient mice. J Neurosci 19: 653-663, 1999.

Clarke VR, Ballyk BA, Hoo KH, Mandelzys A, Pellizzari A, Bath CP, Thomas J, Sharpe EF, Davies CH, Ornstein PL, Schoepp DD, Kamboj RK, Collingridge GL, Lodge D, and Bleakman D. A hippocampal GluR5 kainate receptor regulating inhibitory synaptic transmission. Nature 389: 599-603, 1997.

Contractor A, Swanson GT, Sailer A, O'Gorman S, and Heinemann SF. Identification of the kainate receptor subunits underlying modulation of excitatory synaptic transmission in the CA3 region of the hippocampus. J Neurosci 20: 8269-8278, 2000.

Cossart R, Dinocourt C, Hirsch JC, Merchan-Perez A, De FJ, Esclapez M, Bernard C, AND Ben-ARI Y. Dendritic but not somatic GABAergic inhibition is decreased in experimental epilepsy. Nat Neurosci 4: 52-62, 2001.

Cossart R, Esclapez M, Hirsch JC, Bernard C, and Ben-Ari Y. GluR5 kainate receptor activation in interneurons increases tonic inhibition of pyramidal cells. Nat Neurosci 1: 470-478, 1998.

Frerking M, Malenka RC, AND Nicoll RA. Synaptic activation of kainate receptors on hippocampal interneurons. Nat Neurosci 1: 479-486, 1998.

Frerking M, Schmitz D, Zhou Q, Johansen J, and Nicoll RA. Kainate receptors depress excitatory synaptic transmission at CA3->CA1 synapses in the hippocampus via a direct presynaptic action. J Neurosci 21: 29582966, 2001.

GAIARSA JL, ZAGREAN L, AND BEN-ARI Y. Neonatal irradiation prevents the formation of hippocampal mossy fibers and the epileptic action of kainate on rat CA3 pyramidal neurons. J Neurophysiol 71: 204-215, 1994.

Khalilov I, Dhzala V., Ben-Ari Y, and Khazipov R. Dual role of GABA in the neonatal rat hippocampus. Dev Neurosci 21: 310-319, 1999a.

Khalilov I, Dzhala V, Medina I, Leinekugel X, Melyan Z, Lamsa K, KHAZIPOV R, AND BEN-ARI Y. Maturation of kainate-induced epileptiform activities in interconnected intact neonatal limbic structures in vitro. Eur J Neurosci 11: 3468-3480, 1999b.

Khalilov I, Esclapez M, Medina I, Aggoun D, Lamsa K, Leinekugel X, KhaZIPOV R, AND BEN-ARI Y. A novel in vitro preparation: the intact hippocampal formation. Neuron 19: 743-749, 1997.

LERMA J. Kainate receptors keep the excitement high. Trends Neurosci 24: 139-141, 2001.

Lerma J, Paternain AV, Rodriguez-Moreno A, and Lopez-Garcia JC. Molecular physiology of kainate receptors. Physiol Rev 81: 971-998, 2001.

Miles R AND Wong RK. Excitatory synaptic interactions between CA3 neurons in the guinea pig hippocampus. J Physiol (Lond) 373: 397-418, 1986.

Monaghan DT And COTMAn CW. The distribution of [3H]kainic acid binding sites in rat CNS as determined by autoradiography. Brain Res 252: 91-100, 1982. 
Mulle C, Sailer A, Perez-Otano I, Dickinson-Anson H, Castillo Pe, Bureau I, Maron C, Gage FH, Mann JR, Bettler B, and Heinemann SF. Altered synaptic physiology and reduced susceptibility to kainate-induced seizures in GluR6-deficient mice. Nature 392: 601-605, 1998.

Mulle C, Sailer A, Swanson GT, Brana C, O'Gorman S, Bettler B, and HEINEMANN SF. Subunit composition of kainate receptors in hippocampal interneurons. Neuron 28: 475-484, 2000.

NADLER JV. Minireview: kainic acid as a tool for the study of temporal lobe epilepsy. Life Sci 29: 2031-2042, 1981.

Paternain AV, Herrera MT, Nieto MA, ANd Lerma J. GluR5 and GluR6 kainate receptor subunits coexist in hippocampal neurons and coassemble to form functional receptors. J Neurosci 20: 196-205, 2000
Petralia RS, Wang YX, AND Wenthold RJ. Histological and ultrastructural localization of the kainate receptor subunits, KA2 and GluR6/7, in the rat nervous system using selective antipeptide antibodies. J Comp Neurol 349: 85-110, 1994.

ROBINSON JH AND DEADWYLER SA. Kainic acid produces depolarization of CA3 pyramidal cells in the vitro hippocampal slice. Brain Res 221: 117-127, 1981.

SMITH KL, SZAROwski DH, TURNER JN, AND SwANN JW. Diverse populations of neurons mediated by local circuit excitation in developing hippocampus. J Neurophysiol 74: 650-672, 1995.

TREMblay E, RePresa A, and Ben-Ari Y. Autoradiographic localization of kainic acid binding sites in the human hippocampus. Brain Res 343: $378-$ $382,1985$. 